\title{
Yașlı Hastalarda COVID-19 İnfeksiyonu Prognozuna Etki Eden Durumlar
}

\section{Prognostic Factors of COVID-19 Infection in Older Patients}

\author{
Ömer KARAȘAHIN'(IID), Pınar TOSUN TAȘAR²(IID), Bug̃ra KERGET 3 (IID), Dog̃an Nasır BiNiCi(iiD), \\ Emine Füsun KARAȘAHIN ${ }^{5}$ (ID), Can SEVINÇ̧(ID), Bilge Nur SERIN(IiD), Ayșe ALBAYRAK ${ }^{8}$ (IID)
}

\footnotetext{
${ }^{1}$ Erzurum Bölge Eg̃itim ve Araștırma Hastanesi, İnfeksiyon Hastalıkları ve Klinik Mikrobiyoloji Klinig̃i, Erzurum, Türkiye

${ }^{2}$ Atatürk Üniversitesi Tıp Fakültesi, Geriatri Bilim Dalı, Erzurum, Türkiye

${ }^{3}$ Atatürk Üniversitesi Tıp Fakültesi, Gög̃üs Hastalıkları Anabilim Dalı, Erzurum, Türkiye

${ }^{4}$ Erzurum Bölge Eg̃itim ve Araștırma Hastanesi, İç Hastalıkları Klinig̃i, Erzurum, Türkiye

${ }^{5}$ Erzurum il Sag̃ lık Müdürlüğü, Halk Sag̃lıg̃ı Birimi, Erzurum, Türkiye

${ }^{6}$ Atatürk Üniversitesi Tıp Fakültesi, Nefroloji Bilim Dalı, Erzurum, Türkiye

${ }^{7}$ Atatürk Üniversitesi Tıp Fakültesi, iç Hastalıkları Anabilim Dalı, Erzurum, Türkiye

${ }^{8}$ Atatürk Üniversitesi Tıp Fakültesi, İnfeksiyon Hastalıkları ve Klinik Mikrobiyoloji Anabilim Dalı, Erzurum, Türkiye
}

Makale atıfı: Karaşahin Ö, Tosun Taşar P, Kerget B, Binici DN, Karaşahin EF, Sevinç C ve ark. Yaşlı hastalarda COVID-19 infeksiyonu prognozuna etki eden durumlar. FLORA 2021;26(2):238-48.

\section{Öz}

Giriş: Yaşlı hastalarda COVID-19 infeksiyonu sırasında akut solunum yetmezliği, metabolik asidoz, koagülapati, septik şok gelişebilmekte ve ölümle sonuçlanabilmektedir. Bu nedenle riskli hastaların uygun zamanda seçimi, erken dönemde yoğun bakım izleniminin sağlanması yarar sağlayacaktır. Çalışmamızda COVID-19 infeksiyonunda ölüm için riskli grup olarak gösterilen geriatrik hastalarda prognoza etkisi olan durumların araştırılması amaçlanmıştır.

Materyal ve Metod: Çalışmamıza COVID-19 olası vaka tanımına uygun olarak 65 yaşından büyük 61 hasta çalışmaya dahil edilmiştir. Çalışmaya dahil edilen hastaların, demografik özellikleri, hastane yatışı sırasında akciğer bilgisayarlı tomografi bulguları, nötrofil-lenfosit oranı (NLO), hemoglobin $(\mathrm{g} / \mathrm{dL})$, trombosit sayısı $\left(10^{9} / \mathrm{L}\right)$, alanin aminotransferaz $(A L T)(\mathrm{U} / \mathrm{L})$, aspartat aminotransferaz (AST) (U/L), total bilirubin $(\mathrm{mg} / \mathrm{dL})$, direkt bilirubin $(\mathrm{mg} / \mathrm{dL})$, laktat dehidrogenaz $(\mathrm{LDH})(\mathrm{U} / \mathrm{L})$, kreatinin kinaz $(\mathrm{CK})(\mathrm{U} / \mathrm{L})$, kan üre azotu (blood urea nitrogen, BUN) $(\mathrm{mg} / \mathrm{dL})$, kreatinin $(\mathrm{mg} / \mathrm{dL})$, albümin $(\mathrm{mg} / \mathrm{dL})$, D-dimer $(\mathrm{ng} / \mathrm{mL})$, ferritin $(\mathrm{ng} / \mathrm{mL})$, troponin $(\mathrm{ng} / \mathrm{mL})$ C-reaktif protein $(C R P)(\mathrm{mg} / \mathrm{L})$ ve prokalsitonin $(P C T(\mathrm{ng} / \mathrm{mL})$ gibi biyobelirteç değerleri, izlem sırasında hastada gelişmiş olan komplikasyonları, verilen tedaviler; hasta dosyalarından ve elektronik kayıtlardan geriye dönük olarak kayıt altına alınmıştır.

Bulgular: Çalışmaya dahil edilen hastaların yaş ortalaması $71.13 \pm 7.68$ ve 32 (\%52.5)'si erkekti. Hastane izleminde 18 (\%29.5) hasta yoğun bakım ünitesinde takip edilmiş ve 10 (\%16.4) hasta ölmüştür. Ölüm ile sonuçlanan hastalarda istatistiksel anlamlı olarak daha yaşlı olduğu bulunmuştur. Başlangıçta, nötrofil-lenfosit oranı, LDH, CK, BUN, kreatinin, troponin, D-dimer, CRP ve prokalsitonin değerleri ölen hastalarda daha yüksek saptanırken albümin daha düşük bulunmuştur. Hastanede yatıss süresini istatistiksel olarak anlamlı olarak uzamasına neden olan durumlar ile oluşturulan Cox regresyon modelinde izlem sırasında en yüksek nötrofil/lenfosit oranın mortalite açııından bağımsız risk faktörü olduğu ve ölüm riskini 10.67 kat (\%95 GA 1.183-96.309) artırdığı bulunmuştur ( $p=0.035$ ).

Sonuç: En yüksek nötrofil/lenfosit oranın mortalite açısından bağımsız risk faktörü olduğu ve ölüm riskini 10 kat artırdığı bulunmuştur. Bu hastalarda mortaliteyi azaltmak için yakın izlem ve kapsamlı tedavi gerekmektedir

Anahtar Kelimeler: COVID-19; Ölüm; Yaşlı

Geliș Tarihi/Received: 07/09/2020 - Kabul Ediliș Tarihi/Accepted: 29/10/2020

${ }^{\circledR}$ Telif Haklı 2021 Flora. Makale metnine www.floradergisi.org web adresinden ulașılabilir. 


\title{
ABSTRACT \\ Prognostic Factors of COVID-19 Infection in Older Patients
}

\author{
Ömer KARAȘAHIN', Pınar TOSUN TAȘAR², Bug̃ra KERGET ${ }^{3}$, Dog̃an Nasır BINICici ${ }^{4}$, Emine Füsun KARAȘAHIN ${ }^{5}$, \\ Can SEVINC ${ }^{6}$, Bilge Nur SERIN ${ }^{7}$, Ayșe ALBAYRAK ${ }^{8}$
}

\footnotetext{
${ }^{1}$ Clinic of Infection Diseases and Clinical Microbiology Erzurum Regional Training and Research Hospital, Erzurum, Turkey

${ }^{2}$ Division of Geriatrics, Ataturk University Faculty of Medicine, Erzurum, Turkey

${ }^{3}$ Department of Chest Diseases, Ataturk University Faculty of Medicine, Erzurum, Turkey

${ }^{4}$ Clinic of Internal Diseases, Erzurum Regional Training and Research Hospital, Erzurum, Turkey

${ }^{5}$ Unit of Public Health, Erzurum Provincial Health Directorate, Erzurum, Turkey

${ }^{6}$ Division of Nephrology, Ataturk University Faculty of Medicine, Erzurum, Turkey

${ }^{7}$ Department of Internal Diseases, Ataturk University Faculty of Medicine, Erzurum, Turkey

${ }^{8}$ Department of Infection Diseases and Clinic Microbiology, Ataturk University Faculty of Medicine, Erzurum, Turkey
}

Introduction: COVID-19 can cause acute respiratory failure, metabolic acidosis, coagulopathy, septic shock, and death in older adults. The timely identification of at-risk patients will facilitate early intensive care intervention. Therefore, this study aimed to investigate the prognostic factors of COVID-19 in geriatric patients, a group shown to have higher mortality risk.

Materials and Methods: A total of 61 patients over 65 years of age with presumed COVID-19 were included in the study. Patients' demographic characteristics, chest computed tomography findings at admission, biomarkers such as neutrophil/lymphocyte ratio $(N L R)$, hemoglobin $(g / d L)$, platelet count $\left(10^{9} / L\right)$, alanine aminotransferase $(A L T)(U / L)$, aspartate aminotransferase $(A S T)(U / L)$, total bilirubin $(\mathrm{mg} / \mathrm{dL})$, direct bilirubin $(\mathrm{mg} / \mathrm{dL})$, lactate dehydrogenase $(\mathrm{LDH})(\mathrm{U} / \mathrm{L})$, creatine kinase $(\mathrm{CK})(\mathrm{U} / \mathrm{L})$, blood urea nitrogen $(B U N)$ $(\mathrm{mg} / \mathrm{dL})$, creatinine $(\mathrm{mg} / \mathrm{dL})$, albumin $(\mathrm{mg} / \mathrm{dL})$, D-dimer $(\mathrm{ng} / \mathrm{mL})$, ferritin $(\mathrm{ng} / \mathrm{mL})$, troponin $(\mathrm{ng} / \mathrm{mL})$, C-reactive protein $(C R P)(\mathrm{mg} / \mathrm{L})$, and procalcitonin $(P C T)(\mathrm{ng} / \mathrm{mL})$, complications during follow-up, and treatments received were recorded retrospectively from patient files and electronic records.

Results: Mean age was $71.13 \pm 7.68$ years, and 32 (52.5\%) of the patients were males. During hospitalization, 18 patients (29.5\%) were admitted to the intensive care unit and 10 (16.4\%) died. Non-surviving patients were significantly older. Mean admitting NLR, $L D H, C K, B U N$, creatinine, troponin, D-dimer, CRP, and procalcitonin values were higher and mean albumin level was lower among the non-surviving patients. A Cox regression model based on variables associated with significantly prolonged hospital length of stay showed that highest NLR during follow-up was an independent risk factor for mortality and increased the risk of death by 10.67 times (95\% Confidence Interval: 1.183-96.309) $(p=0.035)$.

Conclusion: Highest NLR was found to be an independent risk factor for mortality and was associated with a 10-fold higher risk of death. Close monitoring and comprehensive treatment are required to reduce mortality in these patients.

Key Words: COVID-19; Mortality; Elderly

\section{GiRiș}

Koranovirüs'ün insanlarda, soğuk algınlığından Orta Doğu Solunum Sendromu (MERS) ve Siddetli Akut Solunum Sendromu (SARS) gibi daha siddetli hastalıklara kadar solunum yolu infeksiyonlarına neden olduğu bilinmektedir ${ }^{[1-4]}$. 31 Aralık 2019'da ilk olarak Cin'in Wuhan kentinde tanımlanmıs ve viral pnömoni olarak tarif edilmiștir. Sonrasında Dünya Sağlık Örgütü tarafindan 12 Ocak 2020'de daha önce insanlarda tespit edilmemis yeni bir koronavirus 2019-nCoV (COVID-19) olarak tanımlanmıștır. Etken virüs SARS-CoV'e yakın benzerliğinden dolayı
SARS-CoV-2 olarak tanımlanmıștır. Hastalığın adı COVID-19 olarak isimlendirilmis ve pandemi olarak kabul edilmiștir ${ }^{[5]}$.

COVID-19 ile infekte olan hastalarm klinik gidișatları farklı olabilmektedir. Hastalığın bulguları arasında ates, kuru öksürük, halsizlik, yorgunluk yer almaktadır. Coğu hastada bulgular grip benzeri olmaktadır ve hızla düzelmektedir. Ancak yașl hastalarda virüs solunum yetmezliğine neden olabilmekte akut solunum yetmezliği (akut respiratuvar distres sendromu, ARDS) metabolik asidoz, koagülopati, septik sok gelișebilmekte ve ölümle sonuçlanabilmektedir ${ }^{[6]}$. Akciğer tomografisi 
hem tanıda hem de takipte önemlidir ${ }^{[7]}$. Erken dönemde buzlu cam alanları, interlobüler septal kalınlașma, parsiyel konsolidasyon ilerleyen dönemlerde de bilateral yaygin konsolidasyon gelișebilmektedir $^{[8,9]}$. Akciŏerdeki tutulum sayısı arttıkça mortalite artmaktadir ${ }^{[6]}$.

COVID-19 hastalarının değerlendirildiği 1625 hastadan olușan bir calıșmada, en yüksek COVID-19 ile ilișkili mortalitenin ileri yașllarda olduğu görülmüștür ${ }^{[10]}$. Klinisyen tedavi bașarısını artırmak ve ölüm riskini azaltmak için ölüm risk faktörlerine dikkat etmeli, kritik hastaları erken tanımlamalı, tıbbi kaynakları rasyonel olarak tahsis etmeli ve tedavi planını zamanında belirlemelidir. $\mathrm{Bu}$ nedenle ağır hastalığı olan hastalarda risk faktörleri değerlendirilmelidir.

Çalıșamızda COVID-19 infeksiyonunda ölüm için riskli grup olarak gösterilen geriatrik hastalarda prognoza etkisi olan durumların araștırılması amaçlanmıștır.

\section{MATERYAL ve METOD}

Calıșmaya 22 Mart ile 6 Haziran 2020 arasında COVID-19 olası vaka tanımına uygun olarak bölgemizdeki Üniversite ve Eğitim Araștırma Hastanesi'ne yatırılan, COVID-19 açısından akciğer bilgisayarlı tomografisi uyumlu ve COVID-19 polimeraz zincir reaksiyon ve/veya hizli antikor testi pozitifliği olan 65 yașından büyük 61 hasta dahil edilmiștir.

Calıșmamız retrospektif kesitsel bir çalıșma olarak kurgulanmıștır. Calıșmaya dahil edilen hastaların demografik özellikleri (yaș, cinsiyet, sigara kullanımları), kronik hastalıkları, hastaneye yatıs sırasındaki yakınmaları, șikayet bașlangıcından hastaneye bașvuru arasında geçen süre, hastaneye bașvuru anındaki vital bulguları, hastane yatıșı sırasında akciğer bilgisayarlı tomografi bulguları, nötrofil-lenfosit oranı (NLO), hemoglobin ( $\mathrm{g} / \mathrm{dL}$ ), trombosit $\left(10^{9} / \mathrm{L}\right)$, alanin aminotransferaz (ALT) (U/L), aspartat aminotransferaz (AST) (U/L), total bilirubin (mg/dL), direkt bilirubin (mg/dL), laktat dehidrohegenaz (LDH) (U/L), kreatinin kinaz (CK) (U/L), kan üre azotu (blood urea nitrogen, BUN) (mg/dL), kreatinin (mg/dL), albuimin (mg/ $\mathrm{dL})$, D-dimer $(\mathrm{ng} / \mathrm{mL})$, ferritin $(\mathrm{ng} / \mathrm{mL})$, troponin $(\mathrm{ng} / \mathrm{mL})$ C-reaktif protein (CRP) $(\mathrm{mg} / \mathrm{L})$ ve prokalsitonin (PCT) $(\mathrm{ng} / \mathrm{mL})$ gibi biyobelirtec değerleri, izlem sırasında hastada gelișmiș olan komplikas- yonlar ARDS, dissemine intravasküler koagülasyon, sekonder bakteriyel infeksiyon, akut renal yetmezlik, miyokard iskemisi, septik sok, yoğun bakım ünitesine yatıs, mekanik ventilasyon, vazopressör kullanımı), verilen tedaviler (yüksek doz C vitamini, immün plazma, favipiravir, antibiyotik, antifungal, steroid kullanımı) hasta dosyalarından ve elektronik kayıtlardan geriye dönük olarak kayit altına alınmıștır.

ARDS, akut bașlangıçlı oksijenasyon indeksi (arteriyel kısmi oksijen basınc1/inspire edilen oksijenin fraksiyonu) $<300 \mathrm{mmHg}$ ve yamalı infiltrasyonlar gösteren akciğer grafisi olarak tanımlanmıstır ${ }^{[6]}$. Hastalar hastaneye yatıs sırasında ölüm gelișenler ve gelișmeyenler olmak üzere ikiye ayrılmıștır.

Hastaların bilgisayarlı tomografi (BT)'lerine bilgi sistem ağından ulașılmıștır. BT bulguları uluslararası terminolojiye göre buzlu cam görünümü, konsolidasyon ve interlobüler septal kalınlașma olarak tanımlanmıștır ${ }^{[11,12]}$. Etkilenen akciğer lobu, sayısı ve tutulan akciğer lobu kaydedilmiștir ${ }^{[13]}$.

Veriler SPSS-21 paket programına kaydedilmiș ve tekrar aynı program kullanilarak analizler yürütülmüștür. Verilerin değerlendirilmesinde tanımlayıcı istatistikler kullanılmıs ve veriler ortanca (en küçük-en büyük değer), sayı ve yüzde dağılımı ile sunulmuștur. Elde edilen veriler mortalite gelișen ve gelișmeyen hastalar açısından karșlaștırılmıștır. Verilerin karșılaștırılmasında Ki-kare ve Mann-Wihthey $U$ testleri kullanılmıștır.

Calıșma için Atatürk Üniversitesi Klinik Olmayan Araștırmalar Etik kurulundan onay alınmıștır (Karar No: 34, Tarih: 07.05.2020).

\section{BULGULAR}

Calıșmaya dahil edilen hastaların yas ortalamas1 $71.13 \pm 7.68$ ve ortancası 68 (en küçük-en buiyuik; 65-96) olup 32 (\%52.5)'si erkekti. Hastane izleminde 18 (\%29.5) hasta yoğun bakım ünitesinde takip edilmiș ve 10 (\%16.4) hasta ölmüștuir.

Hastane yatıșı sırasında hastaların demografik özellikleri, altta yatan hastalıkları, yakınmaları ve vital bulgularının mortalite varlığı açısından dağılımı Tablo 1'de sunulmuștur. Ölüm ile sonuçlanan hastalarda istatistiksel anlamlı olarak daha yașlı olduğu bulunmuștur. Altta yatan hastalıklardan di- 
Tablo 1. Hastane yatışı sırasında hastaların demografik özellikleri, altta yatan hastalıkları, yakınmaları ve vital bulgularının mortalite varlığı açısından dağılımı

\begin{tabular}{|c|c|c|c|}
\hline & \multicolumn{2}{|c|}{ Mortalite } & \multirow[b]{2}{*}{$\mathbf{P}^{*}$} \\
\hline & $\operatorname{Var}(n=10)$ & Yok $(n=51)$ & \\
\hline \multicolumn{4}{|l|}{ Demografik özellikler } \\
\hline Yaş ortanca (en küçük-en büyük) & $80(65-96)$ & $67(65-90)$ & 0.005 \\
\hline \multicolumn{4}{|l|}{ Cinsiyet } \\
\hline Erkek & $4(\% 40.0)$ & $28(\% 54.9)$ & 0.388 \\
\hline Kadın & $6(\% 60.0)$ & $23(\% 45.1)$ & \\
\hline Sigara kullanımı & & & 0.830 \\
\hline Hiç kullanmamış & $6(\% 60.0)$ & $35(\% 68.6)$ & \\
\hline Aktif kullanım & $3(\% 30.0)$ & $13(\% 25.5)$ & \\
\hline Geçmişte kullanım & $1(\% 10.0)$ & $3(\% 5.9)$ & \\
\hline $\begin{array}{l}\text { Şikayet başlangıcından hastaneye başvuru } \\
\text { arasında geçen süre (gün) } \\
\text { Ortanca (en küçük-en büyük) }\end{array}$ & $4(0-7)$ & $2(0-15)$ & 0.133 \\
\hline \multicolumn{4}{|l|}{ Altta yatan hastalık } \\
\hline Diyabetes mellitus & $6(\% 60.0)$ & $9(\% 17.6)$ & 0.004 \\
\hline Hipertansiyon & $7(\% 70.0)$ & $29(\% 56.9)$ & 0.440 \\
\hline Kronik karaciğer hastalığı & - & $1(\% 2.0)$ & 1.000 \\
\hline Kronik böbrek hastalığı & $1(\% 10.0)$ & $1(\% 2.0)$ & 0.303 \\
\hline Kalp yetmezliği & $1(\% 10.0)$ & $5(\% 9.8)$ & 1.000 \\
\hline Koroner arter hastalığı & $4(\% 33.3)$ & $8(\% 15.7)$ & 0.096 \\
\hline Kronik obstrüktif akciğer hastalığı & $3(\% 30.0)$ & $10(\% 19.6)$ & 0.432 \\
\hline Nörolojik hastalık & $2(\% 20.0)$ & $4(\% 7.8)$ & 0.253 \\
\hline Romatolojik hastalık & - & $2(\% 3.9)$ & 1.000 \\
\hline Malignite & $2(\% 20.0)$ & $3(\% 5.9)$ & 0.122 \\
\hline \multicolumn{4}{|l|}{ Başlangıç yakınmaları } \\
\hline Ateş yüksekliği & $5(\% 50.0)$ & $32(\% 63.7)$ & 0.495 \\
\hline Öksürük & $6(\% 60.0)$ & $35(\% 68.6)$ & 0.595 \\
\hline Nefes darlığı & $7(\% 70.0)$ & $22(\% 43.1)$ & 0.120 \\
\hline Baş ağrısı & $1(\% 10.0)$ & $5(\% 9.8)$ & 1.000 \\
\hline Boğaz ağrısı & $1(\% 10.0)$ & $9(\% 17.6)$ & 1.000 \\
\hline Burun akıntısı & - & $1(\% 2.0)$ & 1.000 \\
\hline Koku kaybı & - & $2(\% 3.9)$ & 1.000 \\
\hline Kusma & - & $1(\% 2.0)$ & 1.000 \\
\hline Bulantı & $1(\% 10.0)$ & $2(\% 3.9)$ & 0.421 \\
\hline Somnolans & $6(\% 60.0)$ & $1(\% 2.0)$ & $<0.001$ \\
\hline Karın ağrısı & $1(\% 10.0)$ & $3(\% 5.9)$ & 0.521 \\
\hline Halsizlik & $5(\% 50.0)$ & $10(\% 19.6)$ & 0.101 \\
\hline Miyalji & $2(\% 20.0)$ & $8(\% 15.7)$ & 0.322 \\
\hline İştahsızlık & $3(\% 30.0)$ & $8(\% 15.7)$ & 0.367 \\
\hline İshal & - & $3(\% 5.9)$ & 1.000 \\
\hline
\end{tabular}


Tablo 1. Hastane yatışı sırasında hastaların demografik özellikleri, altta yatan hastalıkları, yakınmaları ve vital bulgularının mortalite varlığı açısından dağııımı (devamı)

\begin{tabular}{lccc} 
& \multicolumn{2}{c}{ Mortalite } & P* \\
\hline Başlangıç vital bulgular & Var $(\mathbf{n = 1 0})$ & Yok $(\mathbf{n = 5 1 )}$ & 1.000 \\
Ateş $\left(>38.3^{\circ} \mathrm{C}\right)$ & & & \\
Hipoksi $\left(\mathrm{So}_{2}<\% 93\right)$ & $5(\% 50.0)$ & $15(\% 29.4)$ & 0.273 \\
Taşikardi $(>125$ atım/dk) & $5(\% 50.0)$ & $5(\% 9.8)$ & 0.115 \\
Hipotansiyon $(90 / 60 \mathrm{~mm} / \mathrm{Hg})$ & $3(\% 30.0)$ & - & $\mathbf{0 . 0 2 5}$ \\
Takipne $(>22 / \mathrm{dk})$ & $2(\% 20.0)$ & $7(\% 13.7)$ & $\mathbf{0 . 0 0 1}$
\end{tabular}

yabetes mellitus, bașlangıc sikayetlerinden somnolans ve bașlangıc vital bulgularında takipne ve hipotansiyon ölen hastalarda istatistiksel anlamlı olarak daha fazla görülmüștür.

Hastane yatıșı sırasında akciğer BT bulgularının mortalite açısından dağılımı Tablo 2'de sunulmuștur. Hastaneye yatıs sırasında etkilenen akciğer lob sayısı üçün üzerinde olması ölenlerde istatistiksel anlamlı olarak daha yüksek sıklıkta bulunmuștur.

Hastane takipleri sırasında gelișen komplikasyon ve uygulanan tedavinin mortalite varlığı aç1sından dağılımı Tablo 2'de sunulmuștur. Komplikasyon gelișimi ve yoğun bakım ünitesinde yatıș1 olup da ölen hastalarda istatistiksel anlamlı olarak daha fazla sıklıkta görülmüș ve ölen hastalarda istatistiksel anlamlı olarak daha fazla tedavi uygulanmıștır. Hastaların tamamı hidroksiklorokin tedavisi almıstır. Hastaların 10 (\%16.3)'unda sekonder bakteriyel infeksiyon gözlenmiștir. Bu hastaların, 4 (\%40.0)'ünde Acinetobacter baumanii, ikișer hastada (\%20) Enterococcus faecalis ve E. coli, birer hastada ise (\%10.0) Koagülaz negatif stafilokok ve Klebsiella pneumoniae tespit edilmiștir.

Hastane yatıșı ve izlem sırasında bazı biyoberteclerin mortalite açısından dağılımı Tablo 4'te sunulmuștur. Başlangıcta NLO, LDH, CK, BUN, kreatinin, troponin, D-dimer, CRP ve prokalsitonin değerleri ölen hastalarda daha yüksek saptanırken, albümin daha düșük bulunmuștur. İzlem sirasinda ölen hastalarda NLO, ALT, AST, LDH, CK, BUN, kreatinin, troponin, D-dimer, CRP ve

Tablo 2. Hastane yatışı sırasında akciğer bilgisayarlı tomografi bulgularının mortalite açısından dağılımı

\begin{tabular}{lccc} 
& \multicolumn{2}{c}{ Mortalite } & P* \\
\hline Bilateral tutulum & Yok & Var & 1.000 \\
Saf buzlu cam görünümü & $8(\% 80.0)$ & $38(\% 74.5)$ & 0.725 \\
Buzlu cam görüntüsü + İnterlobüler septal kalınlaşma & $6(\% 60.0)$ & $34(\% 66.7)$ & 1.000 \\
Buzlu cam görüntüsü + Konsolidasyon & $1(\% 10.0)$ & $7(\% 13.7)$ & 0.319 \\
Buzlu cam görüntüsü > Konsolidasyon & $7(\% 70.0)$ & $26(\% 51.0)$ & 0.470 \\
Konsolidasyon > buzlu cam görüntüsü & $8(\% 80.0)$ & $32(\% 62.7)$ & 0.253 \\
Etkilen akciğer lobu > 3 & $2(\% 20.0)$ & $4(\% 7.8)$ & 0.048 \\
Sağ üst lob & $4(\% 40.0)$ & $7(\% 13.7)$ & 0.101 \\
Sağ orta lob & $5(\% 50.0)$ & $10(\% 196)$ & 0.481 \\
Sağ alt lob & $5(\% 50.0)$ & $18(\% 35.3)$ & 0.673 \\
Sol üst lob & $9(\% 90.0)$ & $41(\% 80.4)$ & 0.101 \\
Sol orta lob & $5(\% 50.0)$ & $10(\% 19.6)$ & 0.100
\end{tabular}


Tablo 3. Hastane takipleri sırasında gelişen komplikasyon ve uygulanan tedavinin mortalite varlığı açısından dağııımı

\begin{tabular}{|c|c|c|c|}
\hline & \multicolumn{2}{|c|}{ Mortalite } & \multirow[b]{2}{*}{$\mathbf{P}^{*}$} \\
\hline & $\operatorname{Var}(n=10)$ & Yok $(n=51)$ & \\
\hline \multicolumn{4}{|l|}{ Komplikasyon } \\
\hline Akut respiratuvar distres sendromu & $3(\% 30.0)$ & - & 0.003 \\
\hline Dissemine intravasküler koagülasyon & $4(\% 40.0)$ & - & $<0.001$ \\
\hline Sekonder bakteriyel infeksiyon & $9(\% 90.0)$ & $1(\% 2.0)$ & $<0.001$ \\
\hline Akut renal yetmezlik & $9(\% 90.0)$ & - & $<0.001$ \\
\hline Miyokard iskemisi & $5(\% 50.0)$ & $1(\% 2.0)$ & $<0.001$ \\
\hline Septik şok & $10(\% 100)$ & $2(\% 3.9)$ & $<0.001$ \\
\hline Yoğun bakım ünitesine yatış & $10(\% 100)$ & $8(\% 15.7)$ & $<0.001$ \\
\hline \multicolumn{4}{|l|}{ Tedavi } \\
\hline Mekanik ventilasyon & $10(\% 100)$ & $1(\% 2.0)$ & $<0.001$ \\
\hline Vazopressör & $10(\% 100)$ & $2(\% 3.9)$ & $<0.001$ \\
\hline Yüksek doz C vitamini & $8(\% 80)$ & $3(\% 5.9)$ & $<0.001$ \\
\hline İmmün plazma & $4(\% 40)$ & - & $<0.001$ \\
\hline Favipiravir & $8(\% 80)$ & $18(\% 35.3)$ & 0.014 \\
\hline Antibiyotik & $10(\% 100)$ & 31 (\%60.8) & 0.023 \\
\hline Antifungal & $5(\% 50)$ & - & $<0.001$ \\
\hline Steroid & $7(\% 70)$ & $3(\% 5.9)$ & $<0.001$ \\
\hline
\end{tabular}

prokalsitonin değerleri daha yüksek bulunurken; albümin ve trombosit sayısı ise daha düșük tespit edilmiștir.

Hastane yatıșı ve izlem sırasında bazı biyobelirteclerin belirlenen kesme noktası değerleriyle mortalite öngörü gücü, duyarlllığ1 ve özgülllüğü Tablo 5'te sunulmuștur. Bașlangıçta en yüksek, prokalsitonin, BUN, D-dimer ve NLO'nun; izlem sırasında ise en yüksek BUN, en yüksek NLO ile en düsüuk albümin düzeyinin mortaliteyi arttırdığı gösterilmiștir.

Hastanede yatıs süresini istatistiksel olarak anlamlı olarak uzamasina neden olan durumlar ile olusturulan Cox regresyon modelinde izlem sirasında en yüksek NLO'nun mortalite açısından bağımsız risk faktörü olduğu ve ölüm riskini 10.67 kat (\%95 GA 1.183-96.309) artırdığı bulunmuștur $(p=0.035)$.

\section{TARTIȘMA}

Aralık 2019 yllında ilk olarak Cin'in Wuhan kentinde tanımlanmıs olan COVID-19 infeksiyonu- na ilk olarak ülkemizde 11 Mart 2020'de rastlanmıștır. Gün gectikçe ülkemizde de vaka sayısı ve ölüm oranı artmaktadır.

COVID-19 infeksiyonunda prognozun en kötü olduğu dönemler hastalığın 7-14. günleri arasındadır; hastalarda solunum yetmezliği ve ciddi pnömoni gelissebilmektedir. Calıșmalarda komorbiditesi yüksek, ileri yașlı olan kișilerde mortalitenin daha yüksek olduğu gösterilmiștir ${ }^{[14]}$. Calıșmamızda da literatürle uyumlu olarak yas ortalaması 80 yas ve yukarısında olanlarda mortalitenin daha yüksek olduğu gösterilmiștir.

Calıșmamızda mortalitesi daha yüksek olan grupta sırasıyla gelișen komplikasyonlar \%100 oranında septik sok, $\% 90$ oranında akut renal yetmezlik, \%90 oranında sekonder bakteriyel infeksiyondur. Akut respiratuvar distres sendromu ise \%30 oranında gözlenmiștir. Cin'de Wuhan'da ortalama yașı 65.7 olan, hem genç hem de yașl1ların dahil olduğu COVID-19 infeksiyonu olan 85 hasta arasında yapilan retrospektif bir calısmada 
Tablo 4. Hastane yatışı ve izlem sırasında bazı biyobelirteçlerin mortalite açısından dağılımı

\begin{tabular}{|c|c|c|c|}
\hline \multirow{2}{*}{$\begin{array}{l}\text { Biyobelirteçler } \\
\text { Başlangıç } \\
\end{array}$} & \multicolumn{2}{|c|}{ Mortalite } & \multirow[b]{2}{*}{$\mathbf{P}^{*}$} \\
\hline & $\operatorname{Var}(n=10)$ & Yok $(n=51)$ & \\
\hline Trombosit sayısı $\left(10^{9} / \mathrm{L}\right)$ & $254(119-353)$ & $202(115-422)$ & 0.325 \\
\hline Hemoglobin (g/dL) & $12.75(10.10-20.40)$ & $14.00(10.60-17.70)$ & 0.059 \\
\hline Nötrofil-lenfosit oranı & $9.07(1.99-16.64)$ & $2.62(0.75-11.44)$ & 0.002 \\
\hline $\operatorname{ALT}(\mathrm{U} / \mathrm{L})$ & $42(9-61)$ & $25(9-142)$ & 0.117 \\
\hline AST (U/L) & $41(19-99)$ & $32(13-106)$ & 0.071 \\
\hline LDH (U/L) & $372.5(284-748)$ & $258(80-620)$ & 0.002 \\
\hline CK $(\mathrm{U} / \mathrm{L})$ & $361.5(45-1360)$ & $88(22.39-646)$ & 0.005 \\
\hline BUN (mg/dL) & $29.9(17.2-139.2)$ & $18.3(5-51)$ & 0.001 \\
\hline Kreatinin (mg/dL) & $1.15(0.83-7.42)$ & $0.89(0.30-2.00)$ & 0.007 \\
\hline Albümin (mg/dL) & $3.5(3-4.7)$ & $4.00(2.82-4.60)$ & 0.030 \\
\hline Total bilirubin (mg/dL) & $0.65(0.25-1.5)$ & $0.54(0.07-1.64)$ & 0.126 \\
\hline Direkt bilirubin (mg/dL) & $0.28(0.06-0.9)$ & $0.19(0.06-1.00)$ & 0.094 \\
\hline D-dimer (ng/mL) & $2487.5(440-6300)$ & $560(100-3500)$ & 0.002 \\
\hline Ferritin (ng/mL) & $645.5(39.1-2000)$ & $282.7(16-1541)$ & 0.213 \\
\hline Troponin (ng/mL) & $0.415(0.01-88.1)$ & $0.01(0.01-42.50)$ & 0.003 \\
\hline C-reaktif protein (mg/L) & $162(26.2-194)$ & $54.1(3-196)$ & 0.037 \\
\hline Prokalsitonin (ng/mL) & $1.24(0.08-46.42)$ & $0.05(0.01-72.78)$ & 0.001 \\
\hline \multicolumn{4}{|l|}{ İzlem } \\
\hline En düşük trombosit sayısı $\left(10^{9} / \mathrm{L}\right)$ & $103(11-440)$ & $169(102-327)$ & 0.001 \\
\hline En düşük hemoglobin (g/dL) & $8.25(4.10-13.20)$ & $13.50(7.70-16.20)$ & 0.223 \\
\hline En yüksek NLO & $10.75(4.12-34.26)$ & $2.44(0.92-10.84)$ & $<0.001$ \\
\hline En yüksek ALT (U/L) & $148(27-519)$ & $37(12-145)$ & $<0.001$ \\
\hline En yüksek AST (U/L) & $538.5(121-822)$ & $38(14-106)$ & $<0.001$ \\
\hline En yüksek LDH (U/L) & $720(309-1242)$ & $301(150-2060)$ & $<0.001$ \\
\hline En yüksek CK (U/L) & $1068(284-6948)$ & $103.5(33-1189)$ & $<0.001$ \\
\hline En yüksek BUN (mg/dL) & $104.2(51.6-188.7)$ & $20.4(10.0-63.4)$ & $<0.001$ \\
\hline En yüksek kreatinin (mg/dL) & $2.99(1.10-7.60)$ & $0.98(0.50-2.67)$ & $<0.001$ \\
\hline En düşük albümin (mg/dL) & $2.09(1.78-2.80)$ & $3.70(2.18-4.60)$ & $<0.001$ \\
\hline En yüksek total bilirubin (mg/dL) & $1.45(0.62-4.40)$ & $0.64(0.26-1.64)$ & $<0.001$ \\
\hline En yüksek direk bilirubin (mg/dL) & $0.67(0.22-3.86)$ & $0.20(0.09-1.00)$ & $<0.001$ \\
\hline En yüksek D-dimer (ng/mL) & $5740(2000-7838)$ & $850(100-64000)$ & $<0.001$ \\
\hline En yüksek ferritin (ng/mL) & $1650(446.1-2000)$ & $287.35(35-1541)$ & $<0.001$ \\
\hline En yüksek troponin $(\mathrm{ng} / \mathrm{mL})$ & $5.42(0.3-2893.3)$ & $0.10(0.01-127.10)$ & $<0.001$ \\
\hline En yüksek C-reaktif protein (mg/L) & $204.5(130.9-496)$ & $76.4(3.41-218)$ & $<0.001$ \\
\hline En yüksek prokalsitonin (ng/mL) & $18.06(1.84-59)$ & $0.05(0.01-72.78)$ & $<0.001$ \\
\hline
\end{tabular}

ALT: Alanin aminotransferaz, AST: Aspartat aminotransferaz, LDH: Laktat dehirogenaz, CK: Kreatinin kinaz, BUN: Kan üre azotu. *Mann-Whitney U testi uygulanmıştır. 


\begin{tabular}{|c|c|c|c|c|c|}
\hline Başlangıç & Kesme noktası & EAA & Duyarlılık & Özgüllük & $\mathbf{p}$ \\
\hline NLO & 4.70 & $0.814(0.665-0.973)$ & $\% 80.0$ & $\% 76.5$ & 0.002 \\
\hline LDH & $811(\mathrm{U} / \mathrm{L})$ & $0.811(0.700-0.921)$ & $\% 100$ & $\% 62.7$ & 0.002 \\
\hline CK & $330.5(\mathrm{U} / \mathrm{L})$ & $0.784(0.596-0.972)$ & $\% 60$ & $\% 93.9$ & 0.005 \\
\hline BUN & $24.8(\mathrm{mg} / \mathrm{dL})$ & $0.838(0.711-0.965)$ & $\% 80$ & $\% 78.0$ & 0.001 \\
\hline Kreatinin & $1.01(\mathrm{mg} / \mathrm{dL})$ & $0.770(0.635-0.904)$ & $\% 80$ & $\% 70.6$ & 0.007 \\
\hline Albümin & $3.64(\mathrm{mg} / \mathrm{dL})$ & $0.719(0.529-0.909)$ & $\% 72.5$ & $\% 80$ & 0.003 \\
\hline D-dimer & $1345(\mathrm{ng} / \mathrm{mL})$ & $0.814(0.646-0.983)$ & $\% 70$ & $\% 87$ & 0.002 \\
\hline Troponin & $0.035(\mathrm{ng} / \mathrm{mL})$ & $0.784(0.643-0.925)$ & $\% 90$ & $\% 68.3$ & 0.006 \\
\hline C-reaktif protein & $152.5(\mathrm{mg} / \mathrm{L})$ & $0.712(0.524-0.900)$ & $\% 60$ & $\% 90$ & 0.036 \\
\hline Prokalsitonin & $0.205(\mathrm{ng} / \mathrm{mL})$ & $0.840(0.730-0.951)$ & $\% 90$ & $\% 78$ & 0.001 \\
\hline \multicolumn{6}{|l|}{ İzlem } \\
\hline NLO & 5.98 & $0.972(0.976-1.000)$ & $\% 90$ & $\% 96.1$ & $<0.001$ \\
\hline ALT & $70(\mathrm{U} / \mathrm{L})$ & $0.894(0.766-1.000)$ & $\% 90$ & $\% 82.4$ & $<0.001$ \\
\hline AST & $113(\mathrm{U} / \mathrm{L})$ & $0.930(0.817-1.000)$ & $\% 90$ & $\% 96.1$ & $<0.001$ \\
\hline LDH & $561(\mathrm{U} / \mathrm{L})$ & $0.895(0.794-0.996)$ & $\% 80$ & $\% 92$ & $<0.001$ \\
\hline CK & $226.5(\mathrm{U} / \mathrm{L})$ & $0.961(0.914-1.000)$ & $\% 100$ & $\% 85.7$ & $<0.001$ \\
\hline BUN & $49.5(\mathrm{mg} / \mathrm{dL})$ & $0.998(0.991-1.000)$ & $\% 100$ & $\% 97.1$ & $<0.001$ \\
\hline Kreatinin & $1.31(\mathrm{mg} / \mathrm{dL})$ & $0.944(0.958-1.000)$ & $\% 90$ & $\% 85.4$ & $<0.001$ \\
\hline Albümin & $2.33(\mathrm{mg} / \mathrm{dL})$ & $0.985(0.958-1.000)$ & $\% 98$ & $\% 90$ & $<0.001$ \\
\hline D-dimer & $1985(\mathrm{ng} / \mathrm{mL})$ & $0.907(0.827-0.987)$ & $\% 100$ & $\% 77.8$ & $<0.001$ \\
\hline Ferritin & $875(\mathrm{ng} / \mathrm{mL})$ & $0.923(0.835-1.000)$ & $\% 80$ & \%91.7 & $<0.001$ \\
\hline Troponin & $0.23(\mathrm{ng} / \mathrm{mL})$ & $0.893(0.803-0.982)$ & $\% 100$ & \%78.6 & $<0.001$ \\
\hline C-reaktif protein & $129.9(\mathrm{mg} / \mathrm{L})$ & $0.944(0.884-1.000)$ & $\% 100$ & $\% 76$ & $<0.001$ \\
\hline Prokalsitonin & $1.805(\mathrm{ng} / \mathrm{mL})$ & $0.937(0.870-0.987)$ & $\% 100$ & $\% 85.4$ & $<0.001$ \\
\hline
\end{tabular}

EAA: Eğri altı alan, ALT: Alanin aminotransferaz, AST: Aspartat aminotransferaz, LDH: Laktat dehirogenaz, CK: Kreatinin kinaz, BUN: Kan üre azotu.

Tablo 6. Hastanede yatış süresine etki eden durumlar

\begin{tabular}{lccc} 
& & Ortalama (\%95 GA) & p \\
\hline En yüksek nötrofil/lenfosit $>5.98$ & Var & $33.2(18.1-48.2)$ & 0.011 \\
Sekonder bakteriyel infeksiyon & Yok & $30.0(30.0)$ & 0.027 \\
& Var & $34.9(23.9-25.3)$ & 0.046 \\
En yüksek ferritin $>875 \mathrm{ng} / \mathrm{mL}$ & Yok & $24.6(21.0-48.8)$ & 0.043 \\
Bilateral akciğer bulguları & Var & $36.9(21.2-52.5)$ & $24.5(23.2-25.7)$ \\
& Yok & $44.0(29.9-58.9)$ & $15.9(14.6-17.1)$ \\
\end{tabular}


mortalitesi yüksek olan grupta en sık gözlenen komplikasyonlar sirasıyla \%94.1 oranında solunum yetmezliği, \%81.2 oranında sok, \%74.1 oranında da akut respiratuvar distres sendromudur ${ }^{[15]}$. Bulgularımızın farklı olmasının nedeni çalıșmamızın daha yașlı grup arasında yapılması, yoğun bakımdaki yatıs süresinin uzunluğu ve buna sekonder gelișen nozokomiyal infeksiyonlarla açılanabilir. Calıșmamızda mortalitesi yüksek olan grupta daha fazla komplikasyon geliștiği, daha fazla yoğun bakım ihtiyaçları olduğu görülmüștür; bu beklenen bir durumdur. Ayrica mortalitesi yüksek olan grupta daha fazla immün plazma verildiği görülmektedir. Bulgularımız literatürle uyumludur ${ }^{[15]}$. Burada akla gelen soru immün plazmanin etkili olmadığı ya da genel durumları kötü olan hastaların tedaviye yanıtsızlığı ile ilișkili olabilir.

COVID-19 infeksiyonu sırasında ates varlığının kötü prognoz göstergesi olduğuna dair calıșmalar vardır $^{[16,17]}$. Ancak çalıșmamızda ates yüksekliği ile mortalite arasında ilișki saptanmamıștır. Bu durum hasta sayımızın azlığı ile ya da yașlanmayla birlikte yașlanan immün sistem nedeniyle bozulmus sitokin ve ateș yanıtı ile açılanabilir. Calıșmamızda uykuya eğilim ile mortalite arasında ilișki saptanmıștır. Bu durumda hipoksi ve hipoksiye sekonder deliryum tablosu ile açklanabilir.

Çalıșmamızda mortalitesi daha yüksek olan grupta daha fazla kortikosteroid kullanıldığı görülmüștür. Yüksek doz steroid kullanılması predispozan bir faktör olmasından ziyade hastalığın ciddiyeti ile iliskili olabilir. Yakın zamanda yapılmıș olan bir calıșmada metilprednizolon tedavisinin COVID-19 infeksiyonu nedeni ile ARDS gelișen hastalarda faydalı olduğu gösterilmiștir ${ }^{[18]}$. Ancak kritik hastalarda kortikosteroid tedavisi dikkatle kullanılmalıdır.

Yakın zamanda yapılan calıșmalarda lenfosit sayısının CRP'ye oraninin ${ }^{[19]}$ trombosit sayısının lenfosite oraninin ${ }^{[20]}$ ve trombositopenin ${ }^{[21]}$ mortalite üzerinde etkili olduğu gösterilmiștir. Laboratuvar değerlerinden lenfopeni varlığının ciddi infeksiyonla ilișkili olduğu gösterilmiștir. Hastalığın patogenezi anlașlamamıștır. COVID-19 infeksiyonunun $\mathrm{T}$ lenfositleri etkilediği ve $\mathrm{T}$ lenfositindeki hasarlanmanın hastanın sağlı durumunu kötüleștirdiği düșünülmektedir ${ }^{[22]}$. Kritik hastalarda löko- sitoz beklenen bir durumdur, akciğerdeki hasarlı olan hücrelerden salınan proinflamatuvar sitokinler makrofajları ve granülositleri uyarmaktadır ${ }^{[23]}$. Bu nedenle NLO bakteriyel infeksiyonların, pnömonide ve tümörlerde prognostik faktör olarak kullanılmaktadir ${ }^{[24-26]}$. Jingyuan Liu ve arkadașları tarafindan 61 COVID-19 hastası arasında yapılan bir çalıșmada NLO'nun mortalite açısından bağımsız risk faktörü olduğu ve ölüm riskini 3.13 kat arttırdığı gösterilmiștir [27]. Bizim çalıșmamızda da literatüre benzer sekilde NLO'nun mortalite açısından bağımsız risk faktörü olduğu ve ölüm riskini 10.67 kat arttırdığı gösterilmiștir.

Ayrıca yapılan calıșmalarda sigara kullanımı ile kronik akciğer hastalığı arasında ilișki olduğu gösterilmiștir ${ }^{[28]}$. Ancak calıșmamızda sigara kullanımı ile kronik akciğer hastalığı arasında ilișki saptanmamıștır; bu durum vaka sayımızın az olması ile açıklanabilir.

Akciğerde etkilenen lob sayısı arttıkça mortalite artmaktadır ${ }^{[8]}$. Calıșmamızda da hastaneye yatıs sırasında etkilenen akciğer lob sayısı üçün üzerinde olanlarda mortalitenin arttığı gözlenmiștir.

Ancak calıșmamızın bazı kısıtlılıkları vardır. Bunlardan biri çalșmamızın retrospektif olması, diğeri hasta sayımızın azlığıdır. U̇çüncüsü mortalite açısından etkili olabileceğini dưșündüğümüz CURB-65, APACHE gibi skorların kullanılmamıs olmasıdır. Dördüncüsü hastanede yatan hastalarda yapılmıs olmasıdır, yani semptomu olup genel durumu daha kötü olan hastalar arasında yapılmıștır, bu nedenle genel durumu orta ya da asemptomatik olan hastalar atlanmıs olabilir. Ancak calıșmamızın güçlü tarafı ise ülkemizdeki COVID-19'un mortalite üzerine etkisinin incelendiği nadir çalıșmalar arasında olmasidir.

Sonuc olarak en yüksek NLO'nun mortalite açısından bağımsız risk faktörü olduğu ve ölüm riskini 10 kat artırdığı bulunmuștur. Bu hastalarda mortaliteyi azaltmak için yakın izlem ve kapsaml tedavi gerekmektedir.

\section{ETIK KURUL ONAYI}

Calıșma için Atatürk Üniversitesi Klinik Olmayan Araștırmalar Etik kurulundan onay alınmıștır (Karar No: 34, Tarih: 07.05.2020). 


\section{ÇIKAR ÇATIŞMASI}

Yazarlar bu makale ile ilgili herhangi bir çkar çatıșması bildirmemișlerdir.

\section{YAZAR KATKISI}

Anafikir/Planlama: ÖK, PTT, AÇ, DNB, BK Analiz/Yorum: ÖK, PTT

Veri Sağlama: BS, CS, PTT, BK

Yazım: PTT, ÖK, BK, FȘK

Gözden Geçirme ve Düzeltme: ÖK, CS, BK Onaylama: AÇ, DNB, BK, ÖK, PTT, BS, CS, FSK,BK

\section{KAYNAKLAR}

1. Kuiken $T$, Fouchier RA, Schutten $M$, Rimmelzwaan $G F$, van Amerongen G, van Riel D, et al. Newly discovered coronavirus as the primary cause of severe acute respiratory syndrome. Lancet. 2003;362(9380):263-70.

2. Drosten C, Gunther S, Preiser W, van der Werf S, Brodt HR, Becker $S$, et al. Identification of a novel coronavirus in patients with severe acute respiratory syndrome. $N$ Engl I Med 2003;348(20):1967-76.

3. de Groot RJ, Baker SC, Baric RS, Brown CS, Drosten C, Enjuanes $L$, et al. Middle East respiratory syndrome coronavirus (MERS-CoV): announcement of the Coronavirus Study Group. J Virol 2013;87(14):7790-2.

4. Zaki AM, van Boheemen S, Bestebroer TM, Osterhaus $A D$, Fouchier RA. Isolation of a novel coronavirus from a man with pneumonia in Saudi Arabia. N Engl J Med 2012;367(19):1814-20.

5. Pierce-Williams RAM, Burd J, Felder L, Khoury R, Bernstein PS, Avila $K$, et al. Clinical course of severe and critical COVID-19 in hospitalized pregnancies: a US cohort study. Am J Obstet Gynecol MFM 2020:100134.

6. Huang C, Wang Y, Li X, Ren L, Zhao J, Hu Y, et al. Clinical features of patients infected with 2019 novel coronavirus in Wuhan, China. Lancet 2020;395(10223):497-506.

7. Fang $Y$, Zhang $H$, Xie J, Lin M, Ying L, Pang P, et al. Sensitivity of chest CT for COVID-19: comparison to RT-PCR. Radiology 2020:200432.

8. Shi H, Han X, Jiang N, Cao Y, Alwalid O, Gu J, et al. Radiological findings from 81 patients with COVID-19 pneumonia in Wuhan, China: a descriptive study. Lancet Infect Dis 2020;20(4):425-34.

9. Bernheim A, Mei X, Huang $M$, Yang $Y$, Fayad ZA, Zhang $N$, et al. Chest CT findings in Coronavirus Disease-19 (COVID-19): Relationship to duration of infection. Radiology 2020;295(3):200463.

10. 1Onder G, Rezza G, Brusaferro S. Case-fatality rate and characteristics of patients dying in relation to COVID-19 in Italy. JAMA 2020;323(18):1775-6.
11. Koo HJ, Lim S, Choe J, Choi SH, Sung H, Do KH. Radiographic and CT Features of Viral Pneumonia. Radiographics 2018;38(3):719-39.

12. Franquet T. Imaging of pulmonary viral pneumonia. Radiology 2011;260(1):18-39.

13. Ooi GC, Khong PL, Muller NL, Yiu WC, Zhou LJ, Ho JC, et al. Severe acute respiratory syndrome: temporal lung changes at thin-section CT in 30 patients. Radiology 2004;230(3):836-44.

14. Chen N, Zhou M, Dong X, Qu J, Gong F, Han Y, et al. Epidemiological and clinical characteristics of 99 cases of 2019 novel coronavirus pneumonia in Wuhan, China: a descriptive study. Lancet 2020;395(10223):507-13.

15. Du $Y, T u L, Z$ hu $P, M u M$, Wang $R$, Yang $P$, et al. Clinical Features of 85 Fatal Cases of COVID-19 from Wuhan. A Retrospective Observational Study. Am I Respir Crit Care Med 2020;201(11):1372-9.

16. Mohamed R, Aleanizy FS, Alqahtani FY, Alanazi MS, Mohamed N. Common Co-morbidities Are Challenging in the Diagnosis of Middle East Respiratory Syndrome (MERS-CoV) in Saudi Arabia. Pak J Biol Sci 2020;23(2):119-25.

17. Liu W, Tao ZW, Wang L, Yuan ML, Liu K, Zhou L, et al. Analysis of factors associated with disease outcomes in hospitalized patients with 2019 novel coronavirus disease. Chin Med J (Engl) 2020;133(9):1032-8.

18. Wu C, Chen X, Cai Y, Xia J, Zhou X, Xu S, et al. Risk factors associated with acute respiratory distress syndrome and death in patients with coronavirus disease 2019 pneumonia in Wuhan, China. JAMA Intern Med 2020;180(7):934-43.

19. Lagunas-Rangel FA. Neutrophil-to-lymphocyte ratio and lymphocyte-to-C-reactive protein ratio in patients with severe coronavirus disease 2019 (COVID-19): a meta-analysis. I Med Virol 2020;92(10):1733-4.

20. Qu R, Ling $Y$, Zhang $Y H$, Wei $L Y$, Chen $X, L i X M$, et al. Platelet-to-lymphocyte ratio is associated with prognosis in patients with coronavirus disease-19. I Med Virol 2020;92(9):1533-41.

21. Lippi G, Plebani M, Henry BM. Thrombocytopenia is associated with severe coronavirus disease 2019 (COVID-19) infections: A meta-analysis. Clin Chim Acta 2020;506:145-8.

22. Liu WJ, Zhao M, Liu K, Xu K, Wong G, Tan W, et al. T-cell immunity of SARS-COV: Implications for vaccine development against MERS-CoV. Antiviral Res 2017;137:82-92.

23. Shi Y, Wang Y, Shao C, Huang J, Gan J, Huang X, et al. COVID-19 infection: the perspectives on immune responses. Cell Death Differ 2020;27(5):1451-4.

24. Berhane M, Melku M, Amsalu A, Enawgaw B, Getaneh Z, Asrie $F$. The role of neutrophil to lymphocyte count ratio in the differential diagnosis of pulmonary tuberculosis and bacterial community-acquired pneumonia: a cross-sectional study at Ayder and Mekelle Hospitals, Ethiopia. Clin Lab 2019;65(4). 
25. Chen $X Q$, Xue $C R$, Hou $P$, Lin $B Q$, Zhang JR. Lymphocyte-to-monocyte ratio effectively predicts survival outcome of patients with obstructive colorectal cancer. World J Gastroenterol 2019;25(33):4970-84.

26. Feng $D Y$, Zhou YQ, Zhou M, Zou XL, Wang YH, Zhang TT. Risk factors for mortality due to ventilator-associated pneumonia in a Chinese Hospital: a retrospective study. Med Sci Monit 2019;25:7660-5.

27. Liu J, Liu Y, Xiang P, Pu L, Xiong H, Li C, et al. Neutrophil-to-lymphocyte ratio predicts critical illness patients with 2019 coronavirus disease in the early stage. J Transl Med 2020;18(1):206.
28. Leung JM, Yang CX, Tam A, Shaipanich T, Hackett $T L$, Singhera GK, et al. ACE-2 expression in the small airway epithelia of smokers and COPD patients: implications for COVID-19. Eur Respir J 2020;55(5):2000688.

\section{Yazıșma Adresi/Address for Correspondence}

Dr. Öğr. Üyesi Pınar TOSUN TAȘAR

Erzurum Bölge Eğitim ve Araștırma Hastanesi, İnfeksiyon Hastalıkları ve Klinik Mikrobiyoloji Kliniŏi, Erzurum-Türkiye

E-posta: pinar.tosun@gmail.com 